\title{
Penggunaan Metode Penugasan Dalam Upaya Meningkatkan Hasil Belajar Siswa pada Tema Tokoh dan Penemuan di Kelas VI SD Negeri 169/X Pandan Makmur
}

\author{
Sukarti \\ SD Negeri 169/X Pandan Makmur \\ JL. Bima Sakit SK 6 Blok C, Pandan Makmur, Jambi, Indonesia. \\ sukarti@email.com
}

\begin{abstract}
This study aims to disclose information and discuss the use of the assignment method in an effort to improve student learning outcomes on the theme of figures and inventions in class VI SD Negeri 169/X Pandan Makmur. This research is included in the type of classroom action research (CAR). This research was carried out in this research was carried out at SD Negeri 169/X Pandan Makmur. The time of this research was carried out in the odd semester of the 2021 - 2022 school year, which began in September 2021. The subjects in this study were 26 grade VI students. The research procedure consisted of two cycles with four stages of research starting from planning, implementing, observing and reflecting. Data collection in this study was carried out using observation sheets, field notes, learning outcomes test sheets, and documents. The data were analyzed using the percentage formula. The results of this study indicate that the Assignment Method on the Theme of Characters and Inventions can improve student learning outcomes in class VI SD Negeri 169/X Pandan Makmur which is characterized by an increase from pre-cycle (27\%), cycle I (65\%), cycle II (88\%).
\end{abstract}

Keywords: Learning Outcomes, Scientific Approach

\begin{abstract}
Abstrak
Penelitian ini bertujuan untuk mengungkapkan informasi dan membahas tentang Penggunaan Metode Penugasan Dalam Upaya Meningkatkan Hasil Belajar Siswa Pada Tema Tokoh dan Penemuan di Kelas VI SD Negeri 169/X Pandan Makmur. Penelitian ini termasuk dalam jenis penelitian tindakan kelas (PTK). Penelitian ini dilaksanakan di Penelitian ini dilaksanakan di SD Negeri 169/X Pandan Makmur. Waktu penelitian ini dilaksanakan pada semester ganjil tahun pelajaran 2021 - 2022, yang dimulai pada bulan September 2021. Subjek dalam penelitian ini adalah siswa kelas VI yang berjumlah 26 orang. Prosedur penelitian terdiri dari dua siklus dengan empat tahap peneletian mulai dari perencanaan, pelaksanaan, observasi dan refleksi. Pengumpulan data dalam penelitian ini dilakukan dengan menggunakan lembar observasi, catatan lapangan, lembar tes hasil belajar, dan dokumen. Data dianalisis dengan menggunakan rumus persentase.Hasil penelitian ini menunjukkan bahwa melalui Metode Penugasan Pada Tema Tokoh dan Penemuan dapat meningkatkan hasil belajar siswa di kelas VI SD Negeri 169/X Pandan Makmur yang ditandai oleh meningkatnya dari pra siklus (27\%), siklus I (65\%), siklus II (88\%).
\end{abstract}

Kata kunci: Hasil Belajar, Pendekatan Ilmiah

Copyright (c) 2021 Sukarti

Corresponding author: Sukarti

Email Address: sukarti@email.com (JL. Bima Sakit SK 6 Blok C, Pandan Makmur, Jambi, Indonesia)

Received 01 December, Accepted 13 December 2021, Published 28 December 2021

\section{PENDAHULUAN}

Menurut UUD 1945 Pasal 31 Ayat 5 menyatakan bahwa pemerintah memajukan ilmu pengetahuan dan teknologi dengan menjunjung tinggi nilai nilai agama dan persatuan bangsa untuk kemajuan peradapan kesejahteraan umat manusia. Menurut UU Sisdiknas No. 20 Tahun 2003 Pasal 1 Ayat 1, Pendidikan adalah usaha sadar terencana untuk mewujudkan suasana belajar dan proses pembelajaran agar peserta didik secara aktif mengembangkan potensi dirinya untuk memiliki 
kekuatan spritual keagamaan, pengendalian diri, kepribadian, kecerdasan, akhlak mulia, serta keterampilan yang diperlukan dirinya, masyarakat, bangsa dan negara.

Tujuan pendidikan nasional adalah untuk mencerdaskan kehidupan bangsa dan mengembangkan manusia Indonesia seutuhnya. Tujuan ini dibuat agar terciptanya manusia yang beriman dan bertakwa kepada Tuhan Yang Maha Esa dan berbudi pekerti luhur, memiliki pengetahuan, keterampilan, kesehatan jasmani dan rohani, kepribadian yang mantap juga mandiri serta juga memiliki tanggung jawab kemasyarakatan dan kebangsaan.

Dalam proses pembelajaran yang dilaksanakan tidak selalu berjalan lancar, tetapi adakalanya mengalami hambatan-hambatan atau kesulitan baik yang dialami guru dalam mengajar maupun kesulitan yang dialami oleh siswa dalam belajar. Pada pelaksanaannya guru dituntut untuk lebih kreatif dalam memahami setiap perubahan yang terjadi di lingkungan sekitar, serta mampu menentukan berbagai macam strategi, metode serta media pembelajaran yang dapat melibatkan siswa aktif dalam proses belajar mengajar agar kegiatan pembelajaran lebih efektif dan efisien.

Berdasarkan observasi awal yang dilakukan di kelas VI SD Negeri 169/X Pandan Makmur masih banyak hasil belajar siswa yang rendah. Hal ini dapat diartikan pembelajaran yang terjadi ada suatu masalah. Oleh karena itu, keberhasilan pencapaian tujuan pembelajaran bergantung pada kemampuan guru dalam memahami dan memilih suatu model serta metode pembelajaran yang sesuai dengan materi yang akan diajarkan. Ketepatan penggunaan metode pembelajaran tersebut sangat bergantung pada tujuan dan isi proses pembelajaran. Sebagaimana diketahui masalah kemandirian belajar selama ini sering terabaikan, seperti yang terjadi khususnya kelas VI SD Negeri 169/X Pandan Makmur.

Berdasarkan hal tersebut maka perlu adanya peranan guru untuk melakukan perbaikan cara mengajar yang memungkinkan siswa terlibat secara aktif dalam belajar, sehingga aktivitas dapat meningkat. Salah satu alternatif adalah melalui penerapan metode penugasan. Metode pemberian tugas atau sering juga disebut dengan resitasi adalah cara penyampaian bahan pelajaran dengan pemberian tugas kepada siswa untuk dikerjakan dalam rentangan waktu tertentu dan hasilnya harus dipertanggungjawabkan kepada guru. Pemberian

tugas ini adalah salah satu cara alternatif untuk lebih menyempurnakan penyampaian tujuan pembelajaran terkhusus. Hal ini disebabkan oleh padatnya materi pelajaran yang harus disampaikan sementara waktu belajar sangat terbatas di dalam kelas.

Berdasarkan latar belakang di atas, agar pembelajaran terlaksana dengan efektif serta siswa lebih berkembang kemampuannya, maka perlu diberi cara pemecahannya dengan menciptakan suasana belajar yang kondusif serta menyesuaikan karakteristik siswa dan perkembangan siswa. Berdasarkan hal tersebut maka peneliti tertarik untuk melakukan penelitian tindakan kelas dengan judul "Penggunaan Metode Penugasan Dalam Upaya Meningkatkan Hasil Belajar Siswa Pada Tema Tokoh dan Penemuan di Kelas VI SD Negeri 169/X Pandan Makmur”. 


\section{METODE}

Penelitian ini termasuk dalam jenis penelitian tindakan kelas (PTK). Penelitian ini dilaksanakan di Penelitian ini dilaksanakan di SD Negeri 169/X Pandan Makmur. Waktu penelitian ini dilaksanakan pada semester ganjil tahun pelajaran 2021 - 2022, yang dimulai pada bulan September 2021. Subjek dalam penelitian ini adalah siswa kelas VI yang berjumlah 26 orang. Prosedur penelitian terdiri dari dua siklus dengan empat tahap peneletian mulai dari perencanaan, pelaksanaan, observasi dan refleksi. Pengumpulan data dalam penelitian ini dilakukan dengan menggunakan lembar observasi, catatan lapangan, lembar tes hasil belajar, dan dokumen. Data dianalisis dengan menggunakan rumus persentase.

\section{HASIL DAN DISKUSI}

\section{Paparan Data Pra Siklus}

Pra siklus merupakan kondisi awal peserta didik sebelum peneliti melakukan kegiatan penelitian di dalam kelas, dengan menggunakan pola pembelajaran konvensional. Selanjutnya, berdasarkan hasil data pra siklus yang diperoleh, peneliti bersama guru lain melakukan evaluasi mengenai metode/model pembelajaran yang dianggap tepat, sebagai bentuk tindakan perbaikan dari proses pembelajaran.

Kegiatan pengambilan data pra siklus dilakukan di kelas VI dengan jumlah siswa 26 orang. Pra siklus dilakukan peneliti dengan cara melaksanakan kegiatan pembelajaran dengan menggunakan metode tanya jawab atau pembelajaran banyak didominasi oleh guru yang diakhiri dengan pelaksanaan tes. Hasil proses pembelajaran terlihat monoton dan berpusat pada guru, tingkat partisipasi peserta didik dalam belajar rendah, kurang termotivasi dalam belajar, banyak siswa yang tidak memperhatikan ketika guru menerangkan pelajaran di depan kelas, dan mengobrol bersama temannya, serta kurang pahamnya siswa saat melakukan tugas yang diberikan oleh guru, sehingga membuat nilai atau hasil belajarnya rendah.

Dampaknya hasil belajar siswa juga rendah, ini dibuktikan dari hasil ulangan harian terakhir sebelum metode yang diterapkan, untuk lebih jelasnya dapat dilihat pada tabel di bawah ini:

Tabel 1. Rekapitulasi Hasil Belajar Siswa Pra Siklus

\begin{tabular}{|c|l|c|l|}
\hline No & \multicolumn{1}{|c|}{ Nama Siswa } & Nilai & \multicolumn{1}{|c|}{ Keterangan } \\
\hline 1 & Ahmad Fendy Al-Faridzi & 68 & Tidak Tuntas \\
\hline 2 & Alvian Nurhidayatullah & 69 & Tidak Tuntas \\
\hline 3 & Anita Marshella & 70 & Tuntas \\
\hline 4 & Citra Sari & 55 & Tidak Tuntas \\
\hline 5 & Desyma Natalia Sihombing & 55 & Tidak Tuntas \\
\hline 6 & Diana Novita & 65 & Tidak Tuntas \\
\hline 7 & Dimas Ady Putra & 68 & Tidak Tuntas \\
\hline 8 & Dimas Miftahul Huda & 69 & Tidak Tuntas \\
\hline 9 & Diva Wulandari & 69 & Tidak Tuntas \\
\hline 10 & Exgri Rexza Frawala & 67 & Tidak Tuntas \\
\hline 11 & Fiky Maulana & 67 & Tidak Tuntas \\
\hline
\end{tabular}




\begin{tabular}{|c|c|c|c|}
\hline 12 & Huda Baidillah & 70 & Tuntas \\
\hline 13 & Irwan Saputra & 69 & Tidak Tuntas \\
\hline 14 & Isnaini Khalifah & 72 & Tuntas \\
\hline 15 & Karmila & 60 & Tidak Tuntas \\
\hline 16 & Lidya Selviani & 80 & Tuntas \\
\hline 17 & Muslmin & 60 & Tidak Tuntas \\
\hline 18 & M. Fahmi Nurhidayatullah & 65 & Tidak Tuntas \\
\hline 19 & Muhammad Janu Shafara & 67 & Tidak Tuntas \\
\hline 20 & Muhammad Oktavino Hensa & 72 & Tuntas \\
\hline 21 & Novri Arya Pratama & 68 & Tidak Tuntas \\
\hline 22 & Saifudin & 67 & Tidak Tuntas \\
\hline 23 & Via Diananta & 67 & Tidak Tuntas \\
\hline 24 & Wahyu Dimas Kurniawan & 60 & Tidak Tuntas \\
\hline 25 & Zaura Tiaramadhani & 75 & Tuntas \\
\hline 26 & Zhaskiya Efrika & 78 & Tuntas \\
\hline \multicolumn{2}{|c|}{ Jumlah } & 1.752 & \\
\hline \multicolumn{2}{|c|}{ Rata-Rata } & 67,38 & \\
\hline \multicolumn{2}{|c|}{ KKM } & 70 & \\
\hline \multicolumn{2}{|c|}{ Jumlah Siswa Yang Tuntas } & \multicolumn{2}{|c|}{7 Orang / 27\% } \\
\hline \multicolumn{2}{|c|}{ Jumlah Siswa Yang Belum Tuntas } & \multicolumn{2}{|c|}{19 Orang / 73\% } \\
\hline
\end{tabular}

Dari tabel di atas dapat dijelaskan bahwa sebelum menerapkan metode penugasan diperoleh rata - rata hasil belajar siswa yaitu 67,38 dengan persentase 27\% atau 7 siswa dari 26 orang yang tuntas belajar. Hasil tersebut menunjukkan bahwa pada pra siklus secara klasikal siswa belum tuntas belajar, karena hanya 7 siswa yang memperoleh nilai $\geq 70$ atau hanya sebesar $27 \%$ yang mencapai kriteria ketuntasan minimum (KKM).

Sehingga, masih terdapat 19 dari 26 siswa yang belum tuntas belajar atau sebanyak $73 \%$. Hasil tersebut lebih kecil dari persentase ketuntasan klasikal dalam proses pembelajaran yang dikehendaki sebesar $80 \%$ siswa yang tuntas. Berdasarkan tabel nilai dan penjelasan nilai pra siklus di atas dapat dilihat lebih jelas pada diagram dibawah ini

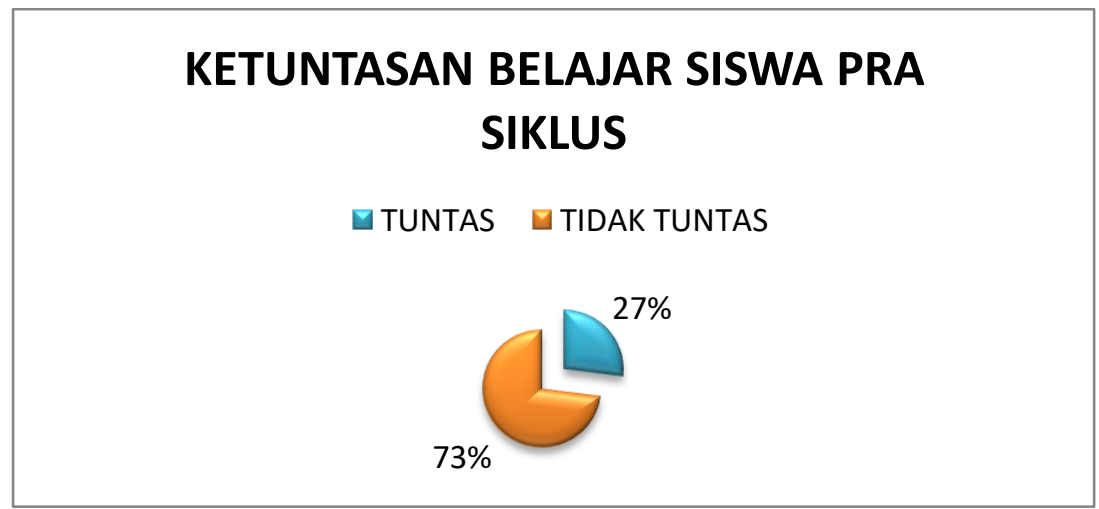

Gambar 1. Ketuntasan Nilai Pra Siklus

Berdasarkan kenyataan di atas, peneliti dibantu oleh teman sejawat (Sawiah, S.Pd.SD) melakukan kajian dan telah yang akan dipergunakan sebagai dasar pertimbangan memilih strategi pembelajaran yang tepat, dalam upaya melakukan tindakan perbaikan pembelajaran. Setelah 
Penggunaan Metode Penugasan Dalam Upaya Meningkatkan Hasil Belajar Siswa pada Tema Tokoh dan Penemuan di Kelas VI SD Negeri 169/X Pandan Makmur, Sukarti

mempertimbangkan berbagai alasan tersebut, peneliti memilih metode penugasan. Metode ini dipergunakan dalam PTK yang akan dilaksanakan pada saat berlangsungnya proses pembelajaran di Kelas VI SDN 169/X Pandan Makmur, yang diharapkan dapat meningkatkan hasil belajar siswa.

\section{Siklus I}

\section{Perencanaan}

Pembelajaran pada penelitian ini menggunakan metode penugasan. Peneliti membuat rencana tindakan seefektif mungkin dengan mengacu pada pola urutan metode penugasan. Pada penelitian siklus I dilaksanakan pembelajaran dengan rencana tindakan sebagai berikut :

1. Mempersiapkan silabus

2. Mempersiapkan RPP

3. Mempersiapkan media pembelajaran power point dan bahan ajar

4. Mempersiapkan instrumen observasi tes siswa dan dokumentasi

5. Mempersiapkan soal UH siklus 1

6. Peneliti menggunakan metode penugasan sebagai solusi pemecahan masalah pembelajaran.

7. Peneliti membuat kelompok-kelompok belajar yang dipilih secara heterogen karakteristik siswa, masing-masing kelompok terdiri dari 4-5 siswa

\section{Pelaksanaan}

Pertemuan pertama pada siklus I ini dilaksanakan pada hari senin, tanggal 6 September 2021 dengan tema pembelajaran tokoh dan penemuannya. Adapun kegiatan pembelajaran dalam pertemuan pertama ini berdasarkan rencana pelaksanaan pembelajaran yang dimulai dari kegiatan pendahuluan, kegiatan inti dan penutup.Pertemuan kedua dilaksanakan pada hari selasa, tanggal 7 September 2021 di kelas VI dengan tema pembelajaran tokoh dan penemuan. Adapun kegiatan dalam pertemuan kedua ini berdasarkan rencana pelaksanaan pembelajaran mulai dari kegiatan pendahuluan, kegiatan inti dan kegiatan penutup.

\section{Observasi}

Sesuai dengan tujuan peneliti yaitu Penggunaan Metode Penugasan Dalam Upaya Meningkatkan Hasil Belajar Siswa pada Tema Tokoh dan Penemuan di Kelas VI SD Negeri 169/X Pandan Makmur, maka pengamatan tindakan dengan menggunakan instrument sebagai berikut. Hasil belajar diperoleh dari tes yang dilakukan pada setiap akhir siklus. Data yang diperoleh berupa angka mengenai nilai yang diperoleh masing-masing siswa terhadap soal yang dikerjakan setelah diterapkannya Metode Penugasan dalam proses pembelajaran. Hasil belajar siswa pada siklus I sebagai berikut:

Tabel 2. Rekapitulasi Hasil Belajar Siswa Siklus I

\begin{tabular}{|c|l|c|l|}
\hline No & \multicolumn{1}{|c|}{ Nama Siswa } & Nilai & \multicolumn{1}{|c|}{ Keterangan } \\
\hline 1 & Ahmad Fendy Al-Faridzi & 72 & Tuntas \\
\hline 2 & Alvian Nurhidayatullah & 75 & Tuntas \\
\hline 3 & Anita Marshella & 70 & Tuntas \\
\hline 4 & Citra Sari & 60 & Tidak Tuntas \\
\hline
\end{tabular}




\begin{tabular}{|c|c|c|c|}
\hline 5 & Desyma Natalia Sihombing & 60 & Tidak Tuntas \\
\hline 6 & Diana Novita & 75 & Tuntas \\
\hline 7 & Dimas Ady Putra & 68 & Tidak Tuntas \\
\hline 8 & Dimas Miftahul Huda & 69 & Tidak Tuntas \\
\hline 9 & Diva Wulandari & 69 & Tidak Tuntas \\
\hline 10 & Exgri Rexza Frawala & 67 & Tidak Tuntas \\
\hline 11 & Fiky Maulana & 70 & Tuntas \\
\hline 12 & Huda Baidillah & 70 & Tuntas \\
\hline 13 & Irwan Saputra & 70 & Tuntas \\
\hline 14 & Isnaini Khalifah & 72 & Tuntas \\
\hline 15 & Karmila & 60 & Tidak Tuntas \\
\hline 16 & Lidya Selviani & 85 & Tuntas \\
\hline 17 & Muslmin & 62 & Tidak Tuntas \\
\hline 18 & M. Fahmi Nurhidayatullah & 70 & Tuntas \\
\hline 19 & Muhammad Janu Shafara & 72 & Tuntas \\
\hline 20 & Muhammad Oktavino Hensa & 72 & Tuntas \\
\hline 21 & Novri Arya Pratama & 70 & Tuntas \\
\hline 22 & Saifudin & 70 & Tuntas \\
\hline 23 & Via Diananta & 70 & Tuntas \\
\hline 24 & Wahyu Dimas Kurniawan & 65 & Tidak Tuntas \\
\hline 25 & Zaura Tiaramadhani & 75 & Tuntas \\
\hline 26 & Zhaskiya Efrika & 78 & Tuntas \\
\hline \multicolumn{2}{|c|}{ Jumlah } & 1.816 & \\
\hline \multicolumn{2}{|c|}{ Rata-Rata } & 69,85 & \\
\hline \multicolumn{2}{|c|}{ KKM } & 70 & \\
\hline \multicolumn{2}{|c|}{ Jumlah Siswa Yang Tuntas } & \multicolumn{2}{|c|}{17 Orang / 65\% } \\
\hline \multicolumn{2}{|c|}{ Jumlah Siswa Yang Belum Tuntas } & \multicolumn{2}{|c|}{9 Orang / 35\% } \\
\hline
\end{tabular}

Dari tabel di atas dapat dijelaskan bahwa setelah menerapkan Metode Penugasan diperoleh rata - rata hasil belajar siswa yaitu 69,85 dengan persentase $65 \%$ atau 17 siswa dari 26 orang yang tuntas belajar. Sehingga masih terdapat $35 \%$ atau 9 orang lagi yang belum tuntas belajar. Hasil tersebut menunjukkan bahwa pada siklus I secara klasikal siswa sudah banyak yang tuntas belajar, namun ketuntasan yang dikehendaki belum mencapai target yang diinginkan sebesar 80\% siswa yang tuntas. Berdasarkan tabel nilai dan penjelasan nilai siklus I di atas dapat dilihat lebih jelas pada diagram di bawah ini:

KETUNTASAN BELAJAR SISWA SIKLUS I

$\square$ TUNTAS $\square$ TIDAK TUNTAS

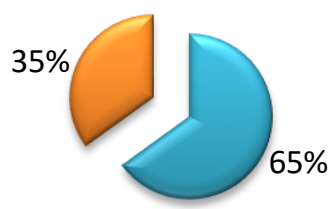

Gambar 2. Ketuntasan Nilai Siklus I 
Penggunaan Metode Penugasan Dalam Upaya Meningkatkan Hasil Belajar Siswa pada Tema Tokoh dan Penemuan di Kelas VI SD Negeri 169/X Pandan Makmur, Sukarti

Berdasarkan kenyataan di atas, peneliti dibantu oleh teman sejawat (Sawiah, S.Pd. SD) melakukan kajian dan telah yang akan dipergunakan sebagai dasar pertimbangan dalam siklus I ini untuk lebih baik ke siklus berikutnya.

\section{Refleksi}

Refleksi tindakan pada siklus I ini lebih difokuskan pada permasalahan yang muncul dan keberhasilan yang tampak selama pembelajaran. Berdasarkan hasil diskusi yang dilakukan dengan observer (Sawiah, S.Pd. SD) yang dilaksanakan di ruang majelis guru. Adapun Permasalahan yang ditemukan selama proses pembelajaran berlangsung adalah:

1. Siswa banyak yang rebut

2. Pembagian kelompok yang tidak heterogen

3. Kurangnya contoh soal

4. Kurang banyak melibatkan siswa

5. Siswa terlihat menampung saja apa yang diberikan guru

Pemecahan masalah:

1. Guru memberikan motivasi dan penilaian proses terhadap aktifitas siswanya

2. Guru memberikan berupa lembaran kerja siswa untuk membantu siswa memahami materi pembelajaran

3. Guru harus berusaha membuat kelas dengan kondisi yang menyenangkan sehingga siswa bersemangat mengikuti kegiatan pembelajaran.

4. Guru seharusnya membagi kelompok dalam heterogen sehingga kelompok tidak monoton.

5. Guru seharusnya banyak melibatkan siswa baik itu dalam menjawab soal atau membahas soal hasil diskusi.

\section{Siklus II}

\section{Perencanaan}

Pembelajaran pada penelitian ini menggunakan metode penugasan. Peneliti membuat rencana tindakan seefektif mungkin dengan mengacu pada pola urutan model pembelajaran metode penugasan. Pada penelitian siklus II dilaksanakan pembelajaran dengan rencana tindakan sebagai berikut: Mempersiapkan silabus, Mempersiapkan RPP, Mempersiapkan media pembelajaran power point dan bahan ajar, lembar kerja siswa, soal UH siklus 2, Peneliti menggunakan metode penugasan sebagai solusi pemecahan masalah pembelajaran, Peneliti membuat kelompok-kelompok belajar yang dipilih secara heterogen karakteristik siswa, masing-masing kelompok terdiri dari 4-5 siswa .

\section{Pelaksanaan}

Pertemuan pertama dilaksanakan pada hari senin, tanggal 13 September 2021 di kelas VI dengan tema tokoh dan penemuan. Adapun kegiatan dalam pertemuan pertama ini berdasarkan rencana pelaksanaan pembelajaran mulai dari kegiatan pendahuluan, kegiatan inti dan kegiatan penutup. Pertemuan kedua dilaksanakan pada hari Rabu, tanggal 8 September 2021 di kelas VI dengan tema 
pembelajaran tokoh dan penemuah. Adapun kegiatan dalam pertemuan kedua ini berdasarkan rencana pelaksanaan pembelajaran mulai dari kegiatan pendahuluan, kegiatan inti dan kegiatan penutup.

\section{Observasi}

Guru melakukan kegiatan pendahuluan mulai dari membaca salam, pembacaan doa dipimpin oleh ketua kelas, kemudian menanyakan kesiapan siswa untuk kegiatan pembelajaran, Kegiatan motivasi dan apersepsi dilakukan dengan mengajukan pertanyaan kepada siswa, Penyampaian tujuan pembelajaran, materi pokok pembelajaran serta metode penugasan melalui media power point, Siswa dibagi menjadi beberapa kelompok dengan cara berhitung mulai 1 sampai 4, Masing-masing siswa dalam kelompok asal membaca buku referensi dan membuat kesimpulan serta menjawab soal-soal dari tugas yang diberikan. Setelah dilaksanakan tindakan dalam penelitian dampaknya hasil belajar siswa meningkat, ini dibuktikan dari hasil ulangan harian terakhir setelah model pembelajaran ini diterapkan, untuk lebih jelasnya dapat dilihat pada tabel di bawah ini:

Tabel 3. Rekapitulasi Hasil Belajar Siswa Siklus II

\begin{tabular}{|c|c|c|c|}
\hline No & Nama Siswa & Nilai & Keterangan \\
\hline 1 & Ahmad Fendy Al-Faridzi & 75 & Tuntas \\
\hline 2 & Alvian Nurhidayatullah & 80 & Tuntas \\
\hline 3 & Anita Marshella & 85 & Tuntas \\
\hline 4 & Citra Sari & 65 & Tidak Tuntas \\
\hline 5 & Desyma Natalia Sihombing & 70 & Tuntas \\
\hline 6 & Diana Novita & 78 & Tuntas \\
\hline 7 & Dimas Ady Putra & 72 & Tuntas \\
\hline 8 & Dimas Miftahul Huda & 72 & Tuntas \\
\hline 9 & Diva Wulandari & 75 & Tuntas \\
\hline 10 & Exgri Rexza Frawala & 72 & Tuntas \\
\hline 11 & Fiky Maulana & 75 & Tuntas \\
\hline 12 & Huda Baidillah & 80 & Tuntas \\
\hline 13 & Irwan Saputra & 75 & Tuntas \\
\hline 14 & Isnaini Khalifah & 80 & Tuntas \\
\hline 15 & Karmila & 70 & Tuntas \\
\hline 16 & Lidya Selviani & 90 & Tuntas \\
\hline 17 & Muslmin & 68 & Tidak Tuntas \\
\hline 18 & M. Fahmi Nurhidayatullah & 70 & Tuntas \\
\hline 19 & Muhammad Janu Shafara & 72 & Tuntas \\
\hline 20 & Muhammad Oktavino Hensa & 75 & Tuntas \\
\hline 21 & Novri Arya Pratama & 70 & Tuntas \\
\hline 22 & Saifudin & 75 & Tuntas \\
\hline 23 & Via Diananta & 72 & Tuntas \\
\hline 24 & Wahyu Dimas Kurniawan & 68 & Tidak Tuntas \\
\hline 25 & Zaura Tiaramadhani & 78 & Tuntas \\
\hline 26 & Zhaskiya Efrika & 85 & Tuntas \\
\hline \multicolumn{2}{|c|}{ Jumlah } & 1.947 & \\
\hline \multicolumn{2}{|c|}{ Rata-Rata } & 74,88 & \\
\hline \multicolumn{2}{|c|}{ KKM } & 70 & \\
\hline \multicolumn{2}{|c|}{ Jumlah Siswa Yang Tuntas } & \multicolumn{2}{|c|}{23 Orang / 88\% } \\
\hline \multicolumn{2}{|c|}{ Jumlah Siswa Yang Belum Tuntas } & \multicolumn{2}{|c|}{3 Orang / 12\% } \\
\hline
\end{tabular}


Dari tabel di atas dapat dijelaskan bahwa setelah menerapkan metode penugasan di peroleh rata - rata hasil belajar siswa yaitu 74,88 dengan persentase $88 \%$ atau 23 siswa dari 26 orang yang tuntas belajar. Hasil tersebut menunjukkan bahwa pada siklus II secara klasikal siswa sudah tuntas belajar, namun hanya 3 siswa yang memperoleh nilai dibawah $<70$ atau hanya sebesar $12 \%$ yang belum mencapai kriteria ketuntasan minimum (KKM). Hasil tersebut sudah memenuhi target keinginan ketuntasan yang dikehendaki sebesar $80 \%$ siswa yang tuntas sudah tercapai. Berdasarkan tabel nilai dan penjelasan nilai siklus II di atas dapat dilihat lebih jelas pada diagram dibawah ini:

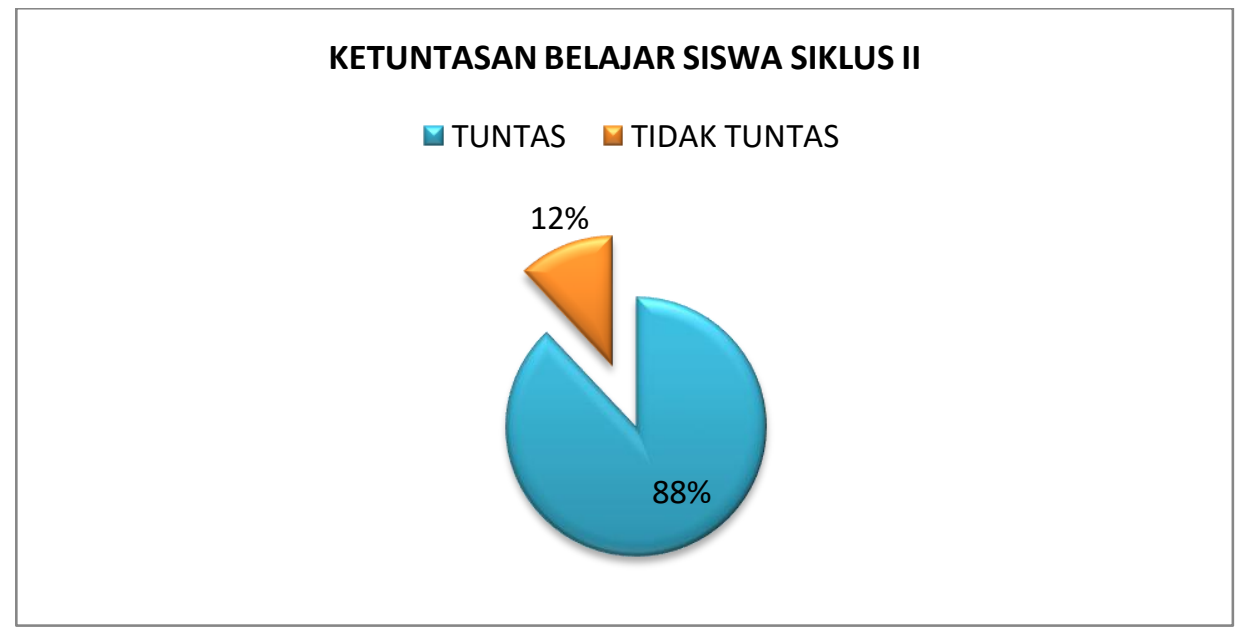

Gambar 3. Ketuntasan Nilai Siklus II

Berdasarkan kenyataan di atas, peneliti dibantu oleh teman sejawat (Sawiah, S.Pd. SD) melakukan kajian dan telah yang akan dipergunakan sebagai dasar pertimbangan dalam siklus II. Pada siklus II ini semua ketuntasan belajar sudah mencapai yang dikehendaki.

\section{Refeleksi Siklus II}

Refleksi tindakan pada siklus II ini adalah perbaikan dari siklus I, berdasarkan hasil diskusi yang dilakukan dengan observer (Sawiah, S.Pd.SD) yang bertempat di ruang majelis guru. Hasil diskusi berkesimpulan siswa sudah mengerti dengan apa yang dijelaskan, guru sudah membagi siswa ke dalam kelompok yang heterogen, siswa sudah aktif dan bertanya dalam kelompok serta sudah aktif disuruh tampil ke depan kelas, sehingga masalah yang ditemukan dalam siklus sebelumnya sudah teratasi dan tidak perlu dilanjutkan ke siklus berikutnya karena target ketuntasan yang diinginkan sudah tercapai.

\section{Diskusi}

Melalui hasil penelitian ini menunjukkan bahwa metode penugasan memiliki dampak positif dalam meningkatkan hasil belajar siswa. Hal ini dapat dilihat dari semakin meningkatnya pemahaman siswa terhadap materi yang disampaikan guru (ketuntasan belajar meningkat dari Pra Siklus, siklus I, dan II yaitu masing-masing $27 \%, 65 \%$, dan $88 \%$. 
Metode Penugasan merupakan salah satu pilihan metode mengajar seorang guru, dimana guru memberikan sejumlah item tes kepada siswanya untuk dikerjakan di luar jam pelajaran. Pemberian item tes ini biasanya dilakukan pada setiap kegiatan belajar mengajar di kelas, pada akhir setiap pertemuan atau akhir pertemuan di kelas. Salah satu strategi belajar yang baik adalah memperbesar frekuensi pengulangan materi / dengan memperbanyak latihan soal-soal sehingga menjadi suatu keterampilan yang dapat melatih diri mendayagunakan pikiran. Metode ini mengandung tiga unsur, antara lain: pemberian tugas, belajar, resitasi. Jadi resitasi lebih luas daripada homework. Akan tetapi keduanya mempunyai kesamaan, antara lain: mempunyai unsur tugas, dikerjakan oleh siswa dan dilaporkan hasilnya, mempunyai unsur didaktis pedagogis. Untuk lebih jelasnya dapat dilihat gambar 4.4 dibawah ini:

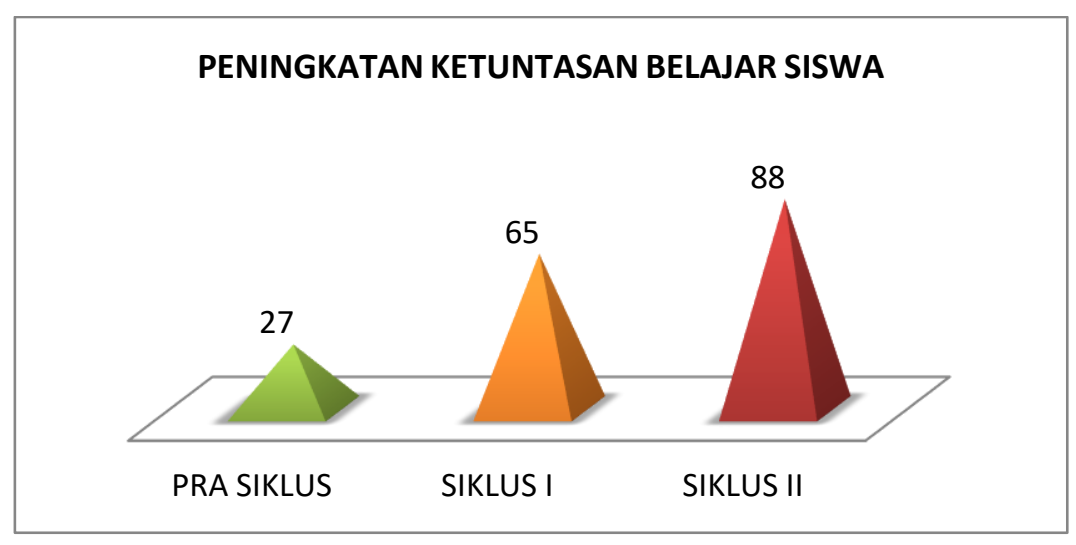

Gambar 4. Peningkatan Ketuntasan Belajar Siswa

\section{KESIMPULAN}

Sesuai dengan rumusan masalah dan tujuan penelitian yang telah dikemukakan tentang penggunaan metode penugasan memberikan dampak positif. Jadi dapat disimpulkan dengan metode penugasan ini dapat meningkatkan hasil belajar siswa di kelas VI di SDN 169/X Pandan Makmur. Dengan adanya model dalam suatu pembelajaran diharapkan dapat meningkatkan hasil belajar siswa. Berbagai macam model dapat digunakan oleh guru dan penggunaan metode penugasan yang dilakukan oleh peneliti dalam penelitian ini merupakan suatu model yang cocok dan sesuai dengan pembelajaran.

Untuk menyempurnakan hasil yang diperoleh dalam penelitian ini maka perlu diajukan beberapa saran berikut perlu dilakukan penelitian lanjutan untuk kelas yang berbeda, untuk itu penulis berharap ada kelanjutan dari penelitian ini sehingga bisa menyempunakan kekurangan dari penelitian yang sebelumnya baik itu dari segi isi maupun dari segi lainnya yang nanti akan menyempurnakan dari penelitian ini. 
Penggunaan Metode Penugasan Dalam Upaya Meningkatkan Hasil Belajar Siswa pada Tema Tokoh dan Penemuan di Kelas VI SD Negeri 169/X Pandan Makmur, Sukarti

\section{REFERENSI}

Agus, Suprijono. (2012). Cooperative Learning: Teori dan Aplikasi Paikem. Yogyakarta: Pustaka Pelajar.

Agus, Nanang Suyono. (2014). Analisis Faktor-Faktor Yang Mempengaruhi Pemilihan Karir Sebagai Akuntan Publik (Studi Empiris Pada Mahsiswa Akuntansi UNSiQ). Jurnal PPKM II. Hal 69-83.

Arends 1997. Model-Model Pembelajaran Inovatif berorientasi Konstuktivitis, Jakarta: Prestasi Pustaka Publisher

Hamalik, Oemar. (2006). Proses Belajar Mengajar. Jakarta: PT. Bumi Aksara.

Oemar Hamalik. (2012). Manajemen Pengembangan Kurikulum. Bandung: Remaja Rosdakarya.

Purwanto. (2011). Evaluasi Hasil Belajar. Yogyakarta: Pustaka Pelajar

Robbins, Anthony. dalam Trianto. Mendesain Model Pembelajaran Inovatif-Progresif. Jakarta: Kencana Prenada Media Group

Rusman. (2012). Model-model Pembelajaran: Mengembangkan Profesionalisme Guru, Raja Grafindo Persada, Jakarta

Sukmadinata, N.S. (2011). Metode Penelitian Pendidikan. Bandung: Remaja Rosadakarya.

Sumiati dan Asra. (2011). Metode Pembelajaran. Bandung: CV. Wacana Prima

Trianto (2009). Mendesain Model Pembelajaran Inovatif Progresif. Surabaya: Kencana.

Trianto. (2012). Model Pembelajaran Terpadu. Jakarta: PT Bumi Aksara.

UUD 1945 Pasal 31 Ayat 5

UU Sisdiknas No. 20 Tahun 2003 Pasal 1 Ayat 1

Winkel. (1999). Psikologi Pengajaran. Jakarta: PT. Gramedia Widiasarana Indonesia. 